\title{
"Estado Laico não é Estado Ateu": algumas reflexões sobre Religião, Estado e Educação a partir da "lei da Bíblia” em Florianópolis/SC
}

Amurabi Oliveira'

\section{Resumo}

O presente trabalho visa a discutir a relação entre Estado e Religião no Brasil tomando como fio condutor a discussão em torno da aprovação da Lei n 9.374, de II de março de 2015, que instituiu a obrigatoriedade da presença da bíblia nas escolas em Florianópolis/SC, a lei foi elaborada pelo vereador Jerônimo Alves (PRB), também conhecido como Bispo Jerônimo Alves. Interessa-me aqui compreender a disputa em torno do conceito de laicidade, por meio da qual determinados grupos passam a almejar a inclusão de suas demandas na agenda política, de tal modo que, na minha compreensão, eles não buscam com as ações que articulam, que perpassam projetos de leis como esse, mas também a institucionalização de novas datas comemorativas e a construção de monumentos de caráter religioso, mas sim uma ampliação semântica do conceito de laicidade, o que se coloca em meio a um processo de expansão pentecostal que ultrapassa as cifras numéricas referentes àqueles que se autodeclaram como evangélicos, especialmente evangélicos pentecostais.

Palavras-chave: Laicidade. Sociologia da Religião. Religião e Política. Religião e Educação.

\section{Introdução}

$\mathrm{O}$ debate sobre religiáo e laicidade apesar de ter passado por um longo tempo relativamente despercebido no Brasil tem ganhado uma significativa visibilidade nas últimas décadas, especialmente no período posterior ao processo de redemocratização política a partir do final dos anos de 1980 e

Doutor em Sociologia pela Universidade Federal de Pernambuco (UFPE), Professor da Universidade Federal de Santa Catarina, atuante em seu Programa de Pós-Graduação em Sociologia Política. Pesquisador do CNPq. 
início da década de 1990, tomando contornos ainda mais singulares com a expansão quantitativa dos evangélicos e sua crescente participação na esfera pública, tanto que, se Pierucci e Mariano (2010, p. 281) afirmam que: "Desde os anos 1960, a sociologia da religião praticada no Brasil tem sido uma sociologia da mudança religiosa e, sobretudo, uma sociologia do catolicismo em declínio". Penso eu que nos últimos anos ela tem sido, sobretudo, uma sociologia da ascensão evangélica, o que tem sido acompanhado crescentemente por uma discussão sobre a atuação desse grupo na construção de uma agenda política no Brasil.

É certo que a questão sobre a laicidade se coloca como um tema em destaque para a intelectualidade nacional desde o processo de constituiçáo da República, ao menos enquanto temática de primeira ordem; porém, por um bom tempo compreendeu-se que essa seria uma questão se não já resolvida, dada a separação formal entre Igreja e Estado, estaria em vias de se resolver considerando o (esperado) crescente processo de secularização da sociedade, de tal modo que esse processo legitimaria e consolidaria o primeiro. Para uma melhor compreensão do problema, parto inicialmente da seguinte definição de laicidade elaborada por Mariano (2011, p. 244):

[...] regulação política, jurídica e institucional das relações entre religião e política, igreja e Estado em contextos pluralistas. Refere-se, histórica e normativamente, à emancipação do Estado e do ensino público dos poderes eclesiásticos e de toda referência e legitimação religiosa, à neutralidade confessional das instituições políticas e estatais, à autonomia dos poderes político e religioso, à neutralidade do Estado em matéria religiosa (ou a concessão de tratamento estatal isonômico às diferentes agremiações religiosas), à tolerância religiosa e às liberdades de consciência, de religião (incluindo a de escolher não ter religião) e de culto.

Todavia, devido aos limites da consolidação de um projeto de sociedade secularizada, que não chega a se concretizar plenamente nem mesmo nos países centrais, tampouco naqueles considerados periféricos, a laicidade aparece crescentemente como uma preocupaçáo constante dos cientistas sociais, emergindo com isso também a necessidade de rever o próprio conceito, por mais que perdure na literatura sociológica o princípio secularista de que a exclusão da religião da esfera pública constitui condição necessária para a democracia (MARIANO, 2011). 
Autores como Berger que em trabalhos anteriores contribuíram para a formulação das chamadas "teorias da secularização" (BERGER, 1985), reelaboraram recentemente seus pontos de vista indicando que:

Argumento ser falsa a suposição de que vivemos em um mundo secularizado. O mundo de hoje, com algumas exceções que logo mencionarei, é tão ferozmente religioso quanto antes, e até mais em certos lugares. Isso quer dizer que toda uma literatura escrita por historiadores e cientistas sociais vagamente chamada de "teoria da secularização" está essencialmente equivocada. Em trabalhos anteriores, contribuí para essa literatura. (BERGER, 2000, p. 10).

Ainda que ele reconheça que a modernidade levou a alguns efeitos secularizantes em determinados segmentos da sociedade, uns mais que outros, ele indica que ela também teria provocado fortes movimentos de contrassecularização. Ou como indica Geertz (2001), os eventos que ocorreram ao longo do último século, como as duas guerras mundiais, a descolonização, a integração tecnológica, a disseminação do populismo etc., "[...] menos contribuíram para impelir a fé para dentro, para as comoções da alma, do que para impulsioná-la para fora, para as comoçóes da sociedade, do Estado e desse tema complexo que chamamos de cultura" (GEERTZ, 2001, p. 152).

A secularização nesse sentido seria algo mais amplo que a ideia de laicidade, pois abarca os diversos âmbitos da vida social, marcadamente por um crescente recuo da influência da religiáo para a esfera privada, ao menos teoricamente.

Desse modo, ainda que laicidade e secularização não sejam termos que se equivalem, encontram-se profundamente imbricados. No caso brasileiro, é importante reconhecer que como:

[...] as religiões estão em toda parte (e, aliás, sempre estiveram), é difícil sustentar que elas estão "fora de seu lugar". Desse modo, as ciências sociais são chamadas a enfrentar de uma nova maneira o problema das relações entre religião e política, em particular, repensando o próprio secularismo que, de ponto de partida impensado do estudo das religiões, se torna ele próprio objeto privilegiado da reflexão. (MONTERO, 2013, p. 20).

Em meio a esta complexa questão que envolve o debate sobre a laicidade do Estado, o campo educacional mostra-se especialmente sensível a esta discussão, tendo em vista não somente o papel central que a Igreja Católica teve 
na constituição deste campo no Brasil (SAVIANI, 2011)² como também as intensas disputas que se colocaram de forma mais explícita, ao menos desde os anos de 1930, em torno do delineamento das políticas educacionais que passariam a emanar do Estado a partir de então ${ }^{3}$.

Pode-se afirmar que a escola republicana representou a mais eficaz das vitrines da laicidade no Brasil, ao mesmo tempo em que possuiu a capacidade de transparecer as inúmeras disputas que se colocavam nesse terreno, principalmente no tocante a questóes mais polêmicas como o Ensino Religioso nos seus diversos modelos.

Neste artigo proponho-me a realizar uma reflexão sobre a relação entre religiaao, educação e laicidade no Brasil a partir de um caso específico, que foi a elaboração e aprovação na cidade de Florianópolis, capital do estado de Santa Catarina, da Lei no 9.374/2015, que instituía a obrigatoriedade da presença de bíblias em escolas públicas e privadas neste município, tendo ficado conhecida como "lei da bíblia". A partir desse caso, busco captar o fenômeno, visto que assume contornos particulares no caso da cidade de Florianópolis, considerando a baixa adesão às religióes evangélicas na cidade.

\section{Religião, política e espaço público}

A ideia de Estado laico, ao menos nos termos que se convencionou compreendê-lo no Brasil, demanda uma separação formal entre religião e atuação política. Ainda que algumas questôes tenham se modificado nos últimos anos, tendo em vista o reconhecimento dos limites das concepçóes mais "radicais" de Estado laico. Como indica Habermas (2007, p. 140) "[...] a exigência laicista de que o Estado deve (em consonância com a liberdade de religião) abster-se de toda política que apoia ou coloca limites à religião enquanto tal constitui uma interpretação por demais estreita desse princípio”.

2 Escaparia do foco e do escopo desse trabalho detalhar o papel central da Igreja Católica no processo de delineação do campo educacional brasileiro, e da própria gênese da complexa relação entre Estado e Religião no plano das políticas educacionais. Para uma melhor análise desse processo vide Cunha (2017).

3 É relevante destacar que foi em 1930, por meio do Decreto no 19.402, que se criou o Ministério dos Negócios da Educação e da Saúde Pública, e que, no ano seguinte, o governo federal requereu à Associação Brasileira de Educação, que congregava intelectuais católicos e liberais a elaboração de um documento que pudesse nortear as políticas públicas em educação no Brasil, todavia a publicação do Manifesto dos Pioneiros da Educação, redigido por Fernando de Azevedo (1894-1974) que foi um dos seus 26 signatários, demarca uma divisão profunda nesta associação (CURY, 1988). 
Ainda segundo Habermas (2003), o Estado deve reconhecer o direito das comunidades de crença de se organizarem segundo suas próprias regras, expressar-se no espaço público e receber apoio do Estado. Porém, isso não pode ultrapassar os limites dos direitos republicanos de liberdade e autonomia. E, apesar do fato de que a linguagem religiosa deva estar presente no espaço do debate público, os argumentos religiosos não devem servir de fundamentação para decisóes de governo, de administração pública ou jurídica.

Burity (2008) coloca que não é mais possível negar a visibilidade pública da religião no cenário contemporâneo, ainda que essa percepção tenha ocorrido por parte dos cientistas sociais no Brasil de forma tardia. $\mathrm{O}$ autor ainda problematiza o fato de que o discurso republicano já se encontra penetrado por uma ampla gama de discursos diferencialistas, e para estes não é mais possível conceber uma democracia sem o pleno reconhecimento da pluralidade que constitui o social. No que diz respeito especificamente ao caso da religiáo:

O desafio da contemporaneidade nas relações entre religião e política não é reafirmar o modelo da separação Igreja-Estado (a própria expressão torna-se cada vez mais caduca, ante a diferenciação do campo das religiões para além do cristianismo no Ocidente) ou a neutralidade das instituições republicanas. É incorporar a conflitividade das lógicas culturais e, entre elas, religiosas, ao cotidiano dos debates públicos, do governo e da representação política. É desdramatizar essa presença no contexto de um republicanismo reconstruído, pluralista, agonístico e democrático, sobre o qual estamos em melhor companhia olhando ao redor e para a frente do que buscando reeditar modelos que de fato são sínteses ex-post a partir de situações contingentes. (BURITY, 2008, p. 98-99).

Para Burity (2008), a questão não é mais “se a religião" deve estar presente na esfera e nas instituiçóes públicas, mas sim "[...] como dar sentido a esta presença, como perceber suas diferentes modalidades, impactos e como avaliar as distintas implicaçôes das relaçōes entre esses atores (e mesmo projetos) religiosos e seus interlocutores e adversários não religiosos [sic]” (p. 93), o que não implica afirmar que todas as posições sejam igualmente válidas ou aceitáveis argumentativa, política e eticamente, cabendo ao debate público e às lutas sociais essa definição, como bem demonstram Campo, Gusmão e Barros Junior (2015).

Estas questôes postas por Burity (2008) se colocam de forma ainda mais complexa ante ao cenário pelo qual passa a América Latina, marcado pela transição católica, em um sentido de redução do número de fiéis, e de uma transição protestante, que demarca a sua expansão (FRESTON, 2010). 
Observamos, assim, a confluência de dois fatores: a) um grupo (bastante heterogêneo) que se expande de forma significativa, inclusive para além das fronteiras do próprio grupo, uma vez que os valores morais do ethos evangélico, especialmente o pentecostal ${ }^{4}$, parece ultrapassar em termos de impacto aqueles que se autodeclaram como tal; b) a constituição de um tipo de cidadania que busca cada vez mais incluir na pauta da agenda política a diversidade cultural, o que implica também a diversidade religiosa.

Essa confluência de fatores passa a impactar diversos campos, dentre os quais, ganha destaque o educacional. Para além das polêmicas que envolvem o Ensino Religioso (CUNHA, 2013, 2014; GIUMBELLI, 2009, 2011), tem ganhado notoriedade no Brasil açôes políticas com impactos sobre a educação escolar, que polemizam ao se afinarem ou contradizerem valores morais considerados relevantes para os cristáos de modo geral, e para os evangélicos de modo particular.

Natividade e Oliveira (2009) apontam para como determinados discursos religiosos conservadores se colocam na arena pública - temas como o Projeto de Lei no 122/2006, proposta voltada à criminalização da homofobia - e são atacados. Além disso:

As ações empreendidas pelo Estado na esfera da gestão e das políticas públicas são também alvo de intensa atenção nesses discursos religiosos. Textos publicados no blog do Movimento de Apoio e no site de Júlio Severo, por exemplo, rotulam o governo Lula de "moralmente falido", responsável pelos avanços promovidos pelo lobby homossexual em seu mandato. O presidente da República é percebido como um dos agentes da corrupção moral

4 Apesar de compartilharem alguns princípios doutrinários com o Protestantismo histórico, como a rejeição da unidade institucional centrada no papa, o estabelecimento da bíblia como única fonte teórica de conhecimento. Para compreendermos as caracteristicas singulares é importante ter em vista que o pentecostalismo poderia ser dividido em três grandes fases ou ondas. A primeira onda surge na década de $1910 \mathrm{com}$ a Congregação Cristã (1910) e a Assembleia de Deus (1911), tendo como ênfase o uso dos dons, principalmente a glossolalia. O segundo periodo de implantação de igrejas englobaria as décadas de 1950 e 1960, tendo como principais representantes as seguintes: Igreja do Evangelho Quadrangular (195I), O Brasil Para Cristo - a primeira a ser fundada por brasileiros (1955) - e, especialmente, a Igreja Deus É Amor (1962), com ênfase no dom da cura. A terceira onda surge no final da década de 1970 e início de 1980, tendo como sua principal representante a Igreja Universal do Reino de Deus (1977) e, com menor representatividade e dissidente da anterior, a Igreja Internacional da Graça de Deus (1980). A ênfase destas últimas recai principalmente no exorcismo e no forte uso dos meios de comunicação. Essas ondas enfatizam a versatilidade pentecostal em termos de teologia, liturgia e ética (FRESTON, 1994, 1999). Para Oro (1996), essas duas últimas ondas constituiriam o que ficou conhecido como neopentecostalismo. 
e sexual dos jovens, não apenas por seu suposto "endosso" às "causas gays", mas também por outras propostas potencialmente danosas, como a "educação sexual" nas escolas e a promoção da equidade de gênero. (NATIVIDADE; OLIVEIRA, 2009, p. I43).

No que diz respeito especificamente às açóes no âmbito escolar, destaca-se a pressão exercida contra o projeto "Escola sem Homofobia", que integrava parte do programa "Brasil sem Homofobia", tendo ficado mais conhecido como Kit Gay, e que acabou sendo vetado pelo governo federal em 2011. Já em 2014, as discussóes sobre a inclusão ou não das questôes relacionadas a gênero e à orientação sexual no Plano Nacional de Educação (PNE) acabaram sendo vetadas, o que ocorreu também em inúmeros planos estaduais e municipais em 2015. É importante frisar que tais açôes foram capitaneadas pelas chamadas "bancadas evangélicas"; porém, não foram realizadas exclusivamente por meio da açáo destas, tendo em vista a capacidade de se alinhar com outros setores da sociedade, bem como o próprio impacto que os argumentos de ordem religiosa têm em diversos grupos.

Pode-se observar assim que não há apenas o desenvolvimento de ações que objetivam incluir demandas específicas nas políticas públicas, acionando recorrentemente a escola como locus privilegiado, mas também de outras que visam à contenção do avanço de direitos de outros grupos que de algum modo, na avaliação dos agentes sociais que são mobilizados nessas iniciativas, vão de encontro a determinados valores morais, apresentados recorrentemente como pertencentes a maior parte da população.

Nesta disputa é interessante perceber que a ideia de "cristão" surge amiúde como um elemento recursivo, tendo em vista que com isso se reforça o argumento de que não se trata apenas de demandadas específicas de uma minoria contra as demandas de outra minoria, mas sim, de uma maioria - e esta incluiria os católicos - que gostaria de ter seus valores resguardados (quando não reforçados). Assim, sendo estes valores morais e religiosos, eles acabam por colocar em xeque não apenas determinada ideia de laicidade mas também de sociedade secularizada ou, ainda, em processo de secularização. Como nos indica Mariano (2011, p. 252):

Num contexto sociocultural pluralista e formalmente democrático, grupos laicos e laicistas têm intensificado sua luta para obter e assegurar o reconhecimento de seus direitos humanos, sexuais, sociais e reprodutivos. Com tal propósito, têm reagido às aspirações, 
propostas e ações de seus adversários religiosos, recorrendo, fundamentalmente, à defesa da laicidade estatal contra interferências religiosas na educação, na saúde, no corpo, nas pesquisas científicas, nas políticas públicas, no ordenamento jurídico-político e nos órgãos estatais. De outro lado, em contraste, católicos e evangélicos têm recrudescido seu ativismo religioso, político e midiático para ampliar a ocupação religiosa do espaço público, influenciar a esfera pública e estatal, promover sua moralidade cristã tradicional e tentar estendê-la ao conjunto da sociedade por meio de lobby e da participação político-partidária.

Minha hipótese é que não estamos diante de açóes de grupos que pretendem minar o Estado laico, pois, de fato, a separação formal entre Igreja e Estado mostra-se como uma peça fundamental para o processo de constituição de um pluralismo religioso (TAYLOR, 2010) e um dinamismo em termos de trânsito e disputa por fiéis, de tal modo que esta é uma condição relevante para a própria dinâmica das denominaçóes evangélicas. Há de se reconhecer que o próprio surgimento dos evangélicos no campo religioso brasileiro possibilitou uma nova dinamicidade, uma vez que "[...] a partir do advento do pentecostalismo, o jogo do 'trânsito' se pluralizou em várias dimensões no interior do campo cristão" (SANCHIS, 2001, p. 15), o que somente fora possível ante a desregulação republicana da esfera religiosa (PIERUCCI, 2013).

Compreendo que o que observamos, ao menos no caso brasileiro, é uma disputa em torno da reelaboração do conceito de laicidade, com alguns grupos buscando ampliar semanticamente seu sentido de modo a acomodar suas demandas, o que é elaborado por meio do acionamento de determinados agentes sociais e de algumas açóes pontuais, de forma mais ou menos articulada, que não necessariamente querem chegar a um objetivo material pragmático e externo (GEERTZ, 2001). Neste caso, a escola mostra-se como um espaço emblemático, tendo em vista que do mesmo modo que ela é (ou foi) uma vitrine de um determinado tipo de concepçáo de Estado laico, ao que me parece ela passa também a ser encarada como uma vitrine das disputas e alargamentos desse conceito.

Este arranjo apenas é possível mediante duas questôes ao menos: a) o reconhecimento de que "[...] o pentecostalismo reflete ou possibilita a criação de uma nova subjetividade que rompe com uma cultura mais ampla” (MARIZ; CAMPOS, 2014, p. 194); b) a expansão do pentecostalismo evangélico, que não se restringe unicamente àqueles que se autodeclaram como pertencentes a este credo, uma vez que o código evangélico-pentecostal tem se 
“[...] disseminado por outras instituiçôes religiosas. Esta expansão tem um alcance maior do que a própria adesão de fiéis ao Pentecostalismo. Se este cresce demograficamente, muito maior tem sido a influência sobre outras religióes assim como na própria sociedade" (ALMEIDA, 2008, p. 55).

Voltar-me-ei no tópico seguinte para a análise de um caso empírico específico, que foi a aprovação de uma lei municipal, em 2015, na cidade de Florianópolis, que tornava obrigatória a presença da bíblia em todas as escolas de Educação Básica da cidade. E esse fato é ainda mais emblemático, considerando-se a baixa adesão a estes credos nessa cidade, já que se trata da segunda capital com menor proporção de evangélicos no país.

\section{As Bíblias em Florianópolis}

A Lei no 9.374, de 11 de março de 2015, é de autoria do vereador Jerônimo Alves Ferreira, membro do Partido Republicano Brasileiro (PRB), que estava cumprindo seu primeiro mandato como vereador em Florianópolis, tendo sido eleito em 2012 com 2.309 votos, e cujo nome na urna eletrônica é Bispo Jerônimo Alves ${ }^{56}$, que faz alusão ao cargo que ocupa dentro da hierarquia da Igreja Universal do Reino de Deus (IURD). Foi ainda candidato a Deputado Estadual em 2014, tendo obtido 27.261 votos, ficando assim na suplência, e não tentou a reeleição com vereador nas eleições municipais de 2016. Vale destacar que a IURD possui fortes vínculos com seu partido, considerando por alguns como um braço político dessa Igreja.

O Projeto de Lei no 15.329 foi apresentado ainda em 2013, e foi aprovado na Câmara dos vereadores; porém, o prefeito Cesar Souza Júnior do Partido Social Democrático (PSD) havia vetado esse projeto em novembro de

5 Importante notar que dentre 368 os candidatos que concorreram a uma das 23 vagas de vereador para 0 municipio de Florianópolis em 2012 a indicação no nome que constava na urna à profissão de pastor/bispo evangélico foi a terceira mais recorrente, com 4 candidatos, ficando atrás de professor, com 12 candidatos, $e$ Doutor (em uma alusão à profissão de médico), com 6 candidatos. No pleito de 2016 foram seis que indicaram a profissão de professor, três de sacerdote de denominação pentecostal e dois de médico.

6 Importante perceber que ele já havia sido candidato em eleições anteriores para outros cargos. Em 2006 concorreu como primeiro suplente da candidata ao senado Rosângela Gomes (PRB) pelo Estado do Rio de Janeiro, e em 2010 concorre ao cargo de deputado federal por Santa Catarina, obtendo 35.556 votos, não tendo sido eleito. Em todo o caso, trata-se de uma carreira política em ascensão, uma vez que em 20 I I é eleito presidente estadual do PRB de Santa Catarina, o reflete também sua proximidade com o primeiro escalão da IURD, como demonstra o fato de ter sido editor da "Folha Universal". 
2014, o que foi embasado pelo parecer da Secretaria Municipal de Educação e da Procuradoria Geral do município. Entretanto, o referido veto foi derrubado, e uma nova versão da lei foi aprovada e publicada no Diário Oficial do Município em 17 de março de 2015, constando a seguinte redação:

Art. $I^{\circ}$ Ficam as unidades escolares públicas e privadas de ensino fundamental e médio obrigadas a manter em suas bibliotecas Bíblias para consulta de seus alunos.

Parágrafo único. Os exemplares deverão ficar em local de destaque, sendo disponibilizados na forma impressa, em braile e áudio.

Art. $2^{\circ}$ Durante e semana que antecede o Dia do Livro, será permitido a instituições que assim desejarem distribuir exemplares da Bíblia nos pátios da escola, desde que acordado previamente com a direção escolar.

Art. $3^{\circ}$ As despesas decorrentes da execução desta Lei correrão por conta de dotações orçamentárias próprias, suplementadas, se necessário.

Art. $4^{\circ}$ Esta Lei entra em vigor na data de sua publicação.

Apesar da comoção que a publicação da lei gerou, o que culminou com a declaração de inconstitucionalidade por parte do Tribunal de Justiça por meio de liminar publicada em 17 de abril de 2015, ela não significou exatamente algo novo em termos de açáo do legislativo da cidade nessa esfera. Ao verificar as atas da Câmara dos Vereadores da cidade, podemos encontrar ao menos quatro leis aprovadas pela casa que poderiam gerar um debate mais amplo com essa mesma tônica. Duas foram aprovadas em 2005: a Lei no 6.717, publicada no Diário Oficial do Município, em 17 de julho de 2005, que estabelece o dia 10 de dezembro como Dia Municipal da Bíblia, e a lei no 6.737, publicada no Diário Oficial do Município em 20 de julho de 2015, que institui a Semana Municipal da Bíblia (inicia na segunda-feira que antecede o segundo domingo do mês de dezembro). Outra, aprovada em 2006, a Lei no 7.219, e publicada no Diário Oficial do Município em 7 de dezembro de 2006, que possui a seguinte redação:

Art. I ${ }^{\circ}$ Fica instituído o dia nove de julho como Dia Municipal da Cultura Evangélica, a ser comemorado anualmente.

Art. $2^{\circ}$ A comemoração ora instituída passa a integrar o calendário oficial de datas e eventos do município de Florianópolis.

Art. $3^{\circ} \mathrm{O}$ Dia Municipal da Cultura Evangélica destina-se ao congraçamento das igrejas evangélicas, independentemente da ordem denominacional protestante, sejam elas tradicionais luteranas, metodistas, batistas, presbiterianas, adventistas, pentecostais ou neo-pentecostais $[\mathrm{sic}]$. 
Art. $4^{\circ}$ Cabe às igrejas a promoção e a divulgação de seus trabalhos evangelísticos, assim como manifestações artísticas e culturais.

Parágrafo único. Entende-se por trabalhos evangelísticos e manifestações artísticas e culturais:

I - apresentação de coral e músicas com arranjos de hinos de louvor e adoração;

II - apresentação de peças de teatro e demais encenações de temas bíblicos;

III - gincanas desportivas e intelectuais visando à integração de membros da igreja com a comunidade;

IV - feira do livro evangélico; e

$\checkmark$ - manifestações que não contraponham com os princípios cristãos evangélicos.

Art. $5^{\circ} \mathrm{O}$ Poder Executivo regulamentará esta Lei, no que couber, no prazo de 60 (sessenta) dias a contar da data de sua publicação.

Art. $6^{\circ}$ Esta Lei entra em vigor na data de sua publicação.

Houve ainda a Lei no 7.915, publicada no Diário Oficial do Município em 30 de julho de 2009, de autoria do vereador Asael Pereira eleito pelo Partido Socialista Brasileiro (PSB), que não conseguiu se reeleger no pleito de $2012^{7}$, que instituiu a semana de celebraçáo da cultura e dos movimentos evangélicos no município de Florianópolis. Neste mesmo ano ele apresentou o projeto de Lei no 13.405/2009, que obrigaria o Poder Executivo a fornecer gratuitamente, através da Secretaria Municipal de Educação, um exemplar do livro A Bíblia Sagrada para cada aluno da rede municipal, quando atingissem a $5^{a}$ série do ensino fundamental, o que foi vetado pela Comissão de Justiça.

No processo de busca pelas leis aprovadas nos últimos anos na Câmara Municipal de Florianópolis, procurei ler as atas que estavam disponibilizadas para consulta, e me chamou a atenção o fato de que o presidente da casa sempre iniciava as atividades invocando a proteçáo de Deus, para, em seguida, declarar aberta a sessão. As atas em sua maioria eram bastante sucintas, de tal modo que o fato de constar esta informação de forma contínua e repetida indica o reconhecimento da relevância de tal ato, por parte não apenas daquele que o realiza como dos demais que compóem a câmara ou ao menos sua maioria.

Chama a atenção esse conjunto de açóes tendo em vista que Florianópolis é a segunda capital brasileira com menor proporção da população que se

7 Obteve 2015 votos no pleito de 2012, ficando na suplência. O ex-vereador foi condenado pelo Tribunal de Justiça de Santa Catarina por improbidade administrativa em 2015, não tendo concorrido a cargos eletivos nos pleitos de 2014 e 2016. 
autodeclara evangélica. Considerando os dados do Censo de 2010, esse grupo representaria apenas $12,81 \%$ da população florianopolitana, contra $22,2 \%$ da média nacional. Ou seja, a elaboração de tais projetos de lei e a eventual aprovação destes não estariam ligadas diretamente ao fato de que encontramos aqui um amplo eleitorado, ainda que essas açóes possam se vincular à busca pela manutenção de um determinado nicho de eleitores.

Como podemos observar, a Lei no 9.374/2015 não foi a primeira aprovada em Florianópolis marcada por um teor religioso; porém, o que a difere substancialmente das outras anteriormente aprovadas diz respeito à materialidade que ela assume através da Bíblia, bem como pelo locus específico de ação para o qual se volta: a escola. Esta instituição, como já indiquei, representaria por excelência a vitrine da laicidade no Brasil; portanto, uma ação que, emanando no Estado, desse materialidade ao aspecto religioso no espaço público, incluindo não somente a escola pública como também as instituições privadas, seria uma afronta direta a essa laicidade.

Asad (2006), analisando o caso francês, aponta que a escola ocupa um relevante lugar ideológico na autorrepresentação da República. E, guardadas as devidas proporçóes, penso que isso ocorre também no Brasil, ainda que para a constituição de nossa República a laicidade não tenha ocupado a mesma centralidade. Compreende-se desse modo que a ação de determinados agentes sociais movidos por valores religiosos constitui um ataque religioso à laicidade da República; porém, não se problematiza o próprio caráter ideológico já posto.

Minha hipótese para esse caso é que a materialidade é um dado fundamental para compreendermos a relevância dessa lei, bem como a visibilidade que ela teve quando aprovada, de tal modo que outras legislaçóes anteriormente aprovadas náo tiveram a mesma repercussão por serem desprovidas dessa característica. Contudo, obviamente houve uma sensível mudança de cenário político nos últimos anos, a qual pode explicar em grande parte as diferentes reaçóes em 2005 e em 2015.

Todavia, a materialidade apenas não seria suficiente para despertar uma ampla comoção como foi o caso, em termos comparativos, a criaçáo de diversos "monumentos à Bíblia" ainda que possam encontrar alguma resistência não desperta as mesmas paixôes. Em 2009, foi inaugurado um monumento em Florianópolis na Praça dos Coqueiros, por iniciativa da Igreja Adventista 
do Sétimo Dia; e, no ano seguinte, o então vereador Asael Pereira (PSB) apresentou o projeto de Lei $n^{\circ} 14.155 / 2010$, que visava a criar um Monumento à Bíblia. Entretanto, este recebeu parecer contrário da Comissão de Justiça. Outros municípios do estado de Santa Catarina aprovaram a construção de obras similares a partir dos anos 2000, em sua maioria por iniciativa do poder público, como Imbituba (2009), Xanxerê (2010), Biguaçu (2011), Brusque (2012), Capão Alto (2014), Santa Cecilia (2014), São Miguel do Oeste (2015), apenas para citar alguns exemplos.

Convém salientar que a escolha da bíblia enquanto elemento material não é realizada de maneira aleatória. Como indicam os resultados da pesquisa conduzida por Almeida (2008, p. 53) em São Paulo:

Dentre os entrevistados (que se caracterizam por não serem definidos a partir de uma religião específica, mas sim por sua condição de circulação no campo religioso), destaco dois artefatos que eram lidos como sendo religiosos para refletir sobre a presença evangélica-pentecostal. Primeiro, a Bíblia apresenta-se como o artefato mais consensual do universo observado para definir o que é ser religioso. Alguns definem que quem é religioso deve lê-la; outros dizem que se alguém a lê com frequência já é religioso; outros se dizem religioso (ou têm fé em deus) porque por vezes lêem [sic] a Bíblia. Enfim, de diferentes maneiras ela era citada, e foi o artefato mais citado, sendo superior às referências à frequência aos serviços religiosos, aos templos, centros, terreiros etc. Em um contexto de privatização da religião, a ideia protestante de acesso direto à Bíblia é bastante funcional.

Além desse apelo, a referência à bíblia possui um elemento retórico relevante que diz respeito a um apelo mais amplo à maioria religiosa presente no Brasil, pois não seria uma referência exclusiva ao universo evangélico, mas sim, ao cristão, englobando também os católicos. Assim, busca-se um apoio mais amplo. Isso é ainda mais relevante no caso de Florianópolis, em razão da pequena, porém crescente, parcela da população que se autodeclara evangélica. Nesse sentido, pode-se compreender que são acionados recursos que se afinam com a diversidade "balbuciante" (PIERUCCI, 2006), ou "acanhada" (TEIXEIRA, 2012) que temos no Brasil, formada por uma maioria esmagadora católica.

A escolha, desse modo, é estratégica, por visibilizar a construção de uma pauta na arena política a partir da religião, ao mesmo tempo em que se mostra cuidadosa em busca de açóes que eventualmente possam contar com um apoio popular mais amplo. Em entrevista ao Jornal Diário Catarinense, 
publicada em 19 de março de $2015^{8}$, o vereador lança mão dos seguintes argumentos para a escolha do livro:

Nós colocamos a Bíblia porque é um livro que praticamente todas as religiões têm acesso. O ateu, aquele que não crê em nada, pode ter acesso à Bíblia, que não pode ser vista apenas como um livro religioso, haja vista que a jurisprudência das nossas leis no Brasil e de muitas leis no mundo foram oriundas da Bíblia sagrada. (DIÁRIO CATARINENSE, 2015, [s. p.]).

E, ao ser indagado se essa lei não feriria o princípio da laicidade, Jerônimo Alves responde ao repórter da seguinte forma:

Estado laico não é Estado ateu, é um onde todas as religiões são defendidas. Temos símbolos em [instituições] públicas que são oriundos da Igreja Católica. Não estamos indo contra a Constituição, que é uma norma pétrea. Nossa intenção de colocar a Bíblia em destaque não foi no intuito de ferir a laicidade do nosso país. (DIÁRIO CATARINENSE, 2015, [s. p.]).

Percebo, na utilização desse recurso discursivo, "Estado laico não é Estado ateu”, uma questão profundamente relevante, que é a afirmação contínua de que não há uma intenção em ferir o princípio da laicidade, a minha hipótese, como já anunciei no tópico anterior, é que está em curso a disputa em torno de uma ampliação semântica desse conceito, de modo que se possa abarcar, com isso, a demanda de novos segmentos sociais que passam a articular suas demandas, principalmente no campo do reconhecimento, na agenda política. Ante essa minha hipótese, parece pertinente a compreensão de secularismo anunciada por Mahmood (2009, p. 833-837):

Secularismo aqui é entendido não apenas como a separação doutrinária da Igreja e do Estado, mas a rearticulação da religião de uma forma que seja compatível com sensibilidades e modos de governança modernos. Repensar o religioso é também repensar o secular e suas reivindicações de verdade, sua promessa de bens internos e externos9. (tradução minha)

Creio que essa compreensão é bastante útil para que os cientistas sociais brasileiros repensarem a forma como compreendem laicidade no Brasil,

8 Entrevista disponivel em: <http://diariocatarinense.clicrbs.com.br/sc/geral/noticia/2015/03/todas-as-religioestem-curiosidade-de-ler-a-biblia-diz-vereador-jeronimo-alves-4722034.html>.

9 "Secularism here is understood not simply as the doctrinal separation of the church and the state but the rearticulation of religion in a manner that is commensurate with modern sensibilities and modes of governance. To rethink the religious is also to rethink the secular and its truth-claims, its promise of internal and external goods". 
principalmente ante ao novo cenário social que vem se desenhando, principalmente diante de um crescente pluralismo religioso que vem acompanhado de um aumento e avanço do segmento evangélico (CAMURÇA, 2013).

O desfecho do caso empírico aqui analisado, como já adiantado, foi o acatamento da Açáo Direta de Inconstitucionalidade no 2015.021853-1, proposta pelo Ministério Público do Estado de Santa Catarina, por seu membro Dr. Basílio Elias De Caro, Procurador de Justiça. A liminar indica "vício formal", pois o que a lei propóe ultrapassa as prerrogativas do legislativo e invade as atribuiçóes privativas do chefe do executivo, e "vício material" do Estado Laico, tendo em vista que, segundo a liminar:

A Constituição Estadual com relação à laicização do Estado, em consonância com a Constituição Federal, permite o ensino religioso, de forma facultativa. Em respeito à liberdade religiosa a Carta Magna não permite a obrigatoriedade e, muito menos, a imposição de uma doutrina religiosa em detrimento de outras e até mesmo de nenhuma. Desta forma, deve o conteúdo programático da disciplina constar a exposição das doutrinas, das práticas, da história e de dimensões sociais das diferentes religiões - bem como de posições não-religiosas [sic] , como o ateísmo e o agnosticismo - sem qualquer tomada de partido por parte dos educadores. (TRIBUNAL DE JUSTIÇA DE SANTA CATARINA, 20I5, [s. p.]).

Além disso, na mesma Ação Direta de Inconstitucionalidade $\mathrm{n}^{\circ}$ 2015.021853-1, indica-se o precedente legal estabelecido pela ação direta de inconstitucionalidade $\mathrm{n}^{\circ} 2.965 / 2011$ contra a Lei $\mathrm{n}^{\circ} 2.965$, de 13 de junho de 2011, do município de Açara, também em Santa Catarina, que obrigava que no início das atividades de cada turno das escolas da rede municipal os professores realizassem a leitura de ao menos um versículo bíblico. Destaco que essa cidade tem $22,26 \%$ da população evangélica, não constituindo, portanto, uma maioria da população.

Voltando para o caso específico de Florianópolis, vale ainda a pena ressaltar a heterogeneidade da comunidade evangélica na cidade, sendo aproximadamente metade identificada como pentecostal, com destaque para a Assembleia de Deus, a Igreja do Evangelho Quadrangular e a igreja Universal do Reino de Deus (IURD), além de uma forte presença do tipo "evangélico não determinado", o que segue uma tendência mais ampla encontrada no último Censo ${ }^{10}$.

10 A população evangélica em Florianópolis é de 54.720 individuos, sendo o grupo mais representativo aqueles que pertencem à religião evangélica pentecostal (26.600), dentro das quais se destacam com maior número 
Chamou-me a atenção o fato de que o Bispo Jerônimo Alves obteve 2.309 votos na eleição municipal de 2012, número quase igual ao número de indivíduos que se autodeclaram em 2010 como pertencentes à IURD (2.736); porém, há de se pressupor que nem todos os adeptos direcionaram seus votos para este político, até mesmo porque nesse conjunto estamos englobando pessoas não aptas para votar e eventuais residentes na cidade cujo título de eleitor pertence a outro município ou, ainda, pessoas que justificaram seu voto. Sua identificação explícita com a IURD poderia ser um fator de resistência por parte de outros evangélicos, tendo em vista a competição existente entre os diversos credos no mercado religioso (GUERRA, 2003), bem como a identificação com as propostas de outros candidatos, os quais podem assumir ou não uma afinidade com a defesa de determinados valores morais e religiosos na esfera pública. Nessa direção, creio que é relevante considerar a ponderação realizada por Mafra (2013, p. 19-20):

Colocarei em dúvida a excessiva valorização dessa notícia em seu input negativo, tendo em vista um outro dado, o do aumento significativo do "evangélico não determinado" (com 9,2 milhões de respondentes). Uma das peculiaridades da IURD em relação ao universo pentecostal e carismático está no fato de esta igreja não recusar uma membresia flutuante. Ao contrário do modelo congregacional cristão reformado - que conta com o princípio da conversão, o abandono dos referentes de sociabilidade anteriores e a reconstrução dos laços de pertencimento a partir de um novo universo valorativo e simbólico (Hefner, 1993) -, a IURD parece não apenas conviver, mas usufruir de uma adesão comunitária frouxa (Mafra; Swatowiski; Sampaio, 2012). Em sua etnografia, Edlaine Gomes (201 I) propõe que a membresia da IURD se divide em quatro estratos, sendo que um deles é de frequentadores esporádicos. Pragmaticamente, isso quer dizer que os frequentadores esporádicos da IURD podem percorrer um circuito variado de igrejas - Assembleia, Deus é Amor, Maranata etc. retornando aos bancos da Universal apenas em momentos especiais: na "Fogueira Santa", diante do fracasso do pagamento de uma dívida, diante da iminência do divórcio etc. Como usam dizer bispos e pastores, a Universal é a igreja "que tem poder"!

O que estou afirmando é que a Universal tem um desenho institucional que não se abala com a não fidelização do frequentador. Isso significa que muitos de seus frequentadores esporádicos, como compõem a sua religião a partir de uma circulação entre várias igrejas, podem perfeitamente se identificar como "evangélicos não determinados". Nesse caso, o inchaço da categoria "evangélico não determinado" no último Censo bem pode ser

de adeptos a Assembleia de Deus (12.59I), a do Evangelho Quadrangular (3.220) e a Igreja Universal do Reino de Deus (2.736), o segundo maior grupo religião evangélica não determinada (14.644), seguindo dos pertencentes à religião evangélica de missão (13.476). 
indicativo de uma rotinização da influência mais abrangente da Universal em todo o campo evangélico, e não a indicação da redução de sua influência.

Poderíamos compreender, portanto, que o sustentáculo político do Bispo Jerônimo Alves se encontra para além daqueles pertencentes ao mesmo credo que o vereador, transbordando, possivelmente, o grupo dos pentecostais, e mesmo dos evangélicos. Sendo assim, suas ações, seguindo a linha de raciocínio das hipóteses que tenho esboçado nesse artigo, visam a captar as demandas desse amplo conjunto de agentes e inseri-las na agenda política, principalmente no que tange ao reconhecimento.

Outro fenômeno que me chamou a atenção foi a não reeleição de Asael Pereira (PSB), autor de inúmeros projetos de lei voltados claramente para uma "pauta cristã", mas que viu seus votos decrescerem de 2.811 para 2.015 entre o pleito de 2008 e de 2012, mesmo considerando que houve aí um crescimento da população evangélica em Florianópolis. Isso pode ser explicado, ao menos em parte, pela que apontam Machado e Burity (2014, p. 625), ao indicarem que já existem sinais dessas tendências "[...] no comportamento eleitoral dos fiéis pentecostais, que parecem ter se tornado mais cuidadosos e seletivos na escolha dos candidatos evangélicos e um pouco mais preocupados com o monitoramento de sua participação em eventos políticos importantes".

Sendo assim, ainda que pareça ser algo de profunda importância para a manutenção de seu eleitorado, a simples ação política visando à inserção de determinas questóes tidas como relevantes para a comunidade evangélica na agenda pública não parece ser suficiente para a manutenção do capital político dos agentes sociais, há uma necessidade de que estas açôes sejam realizadas de forma articuladas com outras questóes que emergem no cenário político brasileiro, principalmente a partir no contexto pós-década de 1980. Como indica Pierucci (2011, p. 7):

A falácia que calça o assentamento dessa inquestionada certeza consiste em tomar como equivalente ao voto das massas religiosas o envolvimento eleitoral dos profissionais da religião (padres, pastores, bispos católicos e evangélicos, até o papa se necessário) seja a favor ou seja contra um dos lados da disputa, mas no fundo sempre em favor da sobrevida da dominação religiosa na totalidade social.

O autor, analisando o caso da eleição presidencial em 2010 no Brasil, aponta para o contraste entre a mobilização das autoridades eclesiásticas e 
a indiferença da maioria religiosa, verificando-se uma recusa em ceder a tais apelos que iriam contra os interesses individuais mais utilitários e materialistas. Ou seja, o êxito na constituição de uma agenda política assentada em princípios religiosos depende da articulação com outras demandas dos agentes, estas mais assentadas no terreno do profano que do sagrado.

As ações políticas pautadas por princípios religiosos do Bispo Jerônimo Alves, substanciadas aqui no caso particular da Lei no 9.374/2015, demonstram a complexidade da relação entre Estado e Religião no Brasil, e que o conceito de secular entendido unicamente como "[...] um regime que supóe a separação entre o aparato burocrático do Estado e o aparato eclesiástico, não é mais capaz de descrever as múltiplas relaçóes entre pluralismos culturais e religiosos e as formas estatais" (MONTERO, 2013, p. 21). Ou outros termos, as mudanças significativas que observamos na realidade empírica convidam os cientistas sociais a repensarem a categoria de laicidade.

A escola nesse caso fica entrincheirada como um alvo preferencial de açóes e pressões; afinal, da mesma forma que o ensino público laico tornou-se símbolo da construção da República, penso que ela assumirá um papel similar nos próximos anos como termômetro das mudanças em cursos, e da capacidade dos agentes sociais se mobilizarem e construírem suas próprias pautas, como foi o caso da Lei no 10.639/2003, que refletiu a capacidade de mobilização dos movimentos sociais negros e de diálogo com o governo federal em uma determinada conjuntura política.

Ainda na entrevista que o vereador concedeu ao Diário Catarinense (2015, [s. p.]), ele afirma que "Eu não vejo a Bíblia como um livro que venha a interferir na questão da laicidade. Vejo que não temos, nas bibliotecas públicas escolares, a Bíblia sagrada”. Ou seja, a questão não me parece que seja, em princípio, o questionamento do Estado laico, mas sim sua ampliação conceitual.

Não quero afirmar com isso que tais açóes náo possam ser problematizadas. Pelo contrário, é a partir de sua inserção na arena política que elas se tornam passíveis de questionamentos de diversas ordens, e de disputas. Porém, interessa-me aqui o fato de que sua elaboração aponta para os limites de determinada compreensão de laicidade, e para a necessidade de avançarmos na reelaboração conceitual visando a uma melhor análise dessa realidade, tendo 
em vista inclusive as mudanças na participação religiosa nas políticas sociais no Brasil (BURITY, 2006).

Isso não significa que devamos cair em um relativismo radical (GEERTZ, 2001), visto que, ante as açóes políticas, deve-se também realizar avaliaçóes políticas, ponderando avanços e retrocessos sociais, e o impacto do reconhecimento de determinados grupos sobre a realidade de outros.

O desafio maior que se coloca para esse processo, ao menos no nível conceitual no meu entender, é aquele que Asad (1983) anuncia para os estudos da religião: como investigar o universo religioso sem partir de uma definiçáo de religião que lhe dá prioridade epistemológica e sem considerá-la como algo secundário que se situa em uma camada menos importante da sociedade?. No final das contas, é com isso que nós cientistas sociais estamos lidando em um Brasil em transformação, especialmente ante a uma maior complexidade na relação entre Estado e Religião.

\section{Considerações finais}

Ao longo desse breve texto busquei refletir sobre a ideia de Estado laico no Brasil, tomando como fio condutor a discussão de torno de uma lei aprovada em 2015 na cidade de Florianópolis, que instituía a obrigatoriedade da bíblia em todas as escolas do município. Tal questão torna-se especialmente relevante nesse novo cenário no qual o povo está mais mobilizado e atiçado em matéria de religião, e o que se deve na perspectiva de Pierucci (2013, p. 55) ao "[...] simples motivo de estarem intensamente mobilizados uns contra os outros, sem férias à vista, os agentes do mercado religioso".

Levantei como hipótese a ideia de que a repercussão dessa aprovação se deveu ao fato de que, ao impor a presença da bíblia nas escolas, a lei, ao mesmo tempo em que dá materialidade a um determinado artefato que é imediatamente reconhecido como um símbolo de religiosidade, age diretamente em uma instituição que pode ser percebida como uma "vitrine" do Estado laico, de tal modo que esta ação é compreendida como uma afronta da determinada concepção de laicidade.

Indiquei, ainda, que o que estaria em questão não seria a tentativa de dissolução da laicidade do Estado, o que náo seria do interesse dos agentes 
sociais que se mobilizam em torno dessa pauta, mas sim a tentativa de uma ampliação semântica desse conceito, de modo a torná-lo mais inclusivo com relação a determinadas questóes de alguns setores da sociedade, notadamente os evangélicos e, mais ainda, os evangélicos pentecostais, ainda que eles utilizem de forma recursiva a identificação de cristãos, de modo a se apresentarem como representantes de demandas de uma maioria da população, o que é especialmente relevante em um contexto como o de Florianópolis, no qual os evangélicos são relativamente pouco representativos, se considerarmos de forma comparativa o cenário nacional.

Meu ponto não é me posicionar de forma favorável ou contrário a esse processo - ampliação semântica do conceito de laicidade torna a relação entre Estado e Religião ainda mais nebulosa certamente -, mas sim demonstrar a complexidade do fenômeno, apontando que dificilmente a relação entre Estado e Religião no Brasil atualmente poderia ser explicada a partir de chaves mais simples. Ao mesmo tempo, essa questão visibiliza a própria "agenda política evangélica” vai para além daqueles que aderem a essa religião, agregando outros agentes.

Afirmo, também, que as açóes como as do Bispo Jerônimo Alves devem ser compreendidas em face de um cenário de expansão pentecostal, que ultrapassa o simples dado numérico referente àqueles que se autodeclaram como pertencentes a denominaçóes evangélicas pentecostais, pois acredito que estaria em curso um processo de pentecostalização da cultura brasileira, especialmente no que diz respeito aos valores morais, o que impacta também setores católicos, evangélicos não pentecostais, e ainda que em menor grau os pertencentes a outras denominaçóes e mesmo os sem religião.

Essa é uma questão difícil de dimensionar, assim como é difícil apontar tendências em médio prazo, uma vez que se imbrica com uma série de outros fatores de ordem contingencial, como questóes econômicas. Porém, os pesquisadores precisam estar mais atentos a tal processo, observando como que essas configurações vão assumindo formas particulares em determinados contextos, e, sobretudo, nas implicações políticas daí decorrentes.

Obviamente que este é um cenário dinâmico e não linear, e apesar de reconhecer que há rupturas entre a cultura evangélica e a cultura brasileira de forma mais ampla (MARIZ; CAMPOS, 2014). Concordo com Almeida 
(2008) que, quanto mais o Brasil se torna pentecostal, mais o pentecostalismo se torna brasileiro. Logo, dentro desse processo de continuidade e ruptura que poderemos melhor compreender as demandas que se estabelecem em torno da concepção de Estado laico. Ademais, como indica Freston (2010), com a estabilização numérica dos protestantes na América Latina em médio prazo, tanto deve ser alterada radicalmente a forma como eles se relacionam com outras religióes, como também com a política.

Acredito, assim, que o desafio está lançado para os cientistas sociais, na busca pela compreensão da complexidade que está envolta na relação entre Estado e Religião, bem como na reformulação das categorias que temos utilizado até então para compreendermos esta realidade no Brasil. Em termos de desafio político, também se coloca como urgente a procura por uma saída democrática para a ampliação semântica da laicidade no Brasil, sem que com isso se construa uma agenda política alinhada com posicionamentos que possam apontar para retrocessos políticos e sociais no nível da redistribuição e do reconhecimento dos demais grupos, especialmente das chamadas minorias.

\section{Referências}

ALMEIDA, R. Os pentecostais serão maioria no Brasil?. REVER, v. 4, p. 48-58, 2008.

ASAD, T. Anthropological conceptions of religion: reflections on Geertz. Man. v. 18, n. 2, p. 237-259, 1983.

French Secularism and the "Islamic Veil Affair". The Hedgehog Review, v. 8, n. 1-2, p. 93-106, 2006.

BERGER, P. L. O Dossel Sagrado: elementos para uma sociologia da religião. São Paulo: Paulinas, 1985.

A dessecularização do mundo: uma visão global. Religiáo \& Sociedade, v. 21, n. 1, p. $9-23,2000$.

BURITY, J. A. Redes, parcerias e participação religiosa nas políticas sociais no Brasil. Recife: Editora Massangana, 2006.

Religião, política e cultura. Tempo Social, v. 20, n. 2, p. 83-113, 2008.

CÂMARA MUNICIPAL DE FLORIANÓPOLIS. Legislação. Disponível em: <http://www. cmf.sc.gov.br/legislacao>. Acesso em: 10 ago. 2015. 
Transparência. Disponível em: <http://www.cmf.sc.gov.br/transparencia>. Acesso em: 10 ago. 2015.

CAMPOS, R. B.; GUSMÃO, E.; BARRETO JUNIOR, C. A disputa pela laicidade: uma análise das interaçóes discursivas entre Jean Wylys e Silas Malafaia. Religiáo \& Sociedade, v. 35, n. 2, p. 165-188, 2015.

CAMURÇA, M. O Brasil Religioso que Emerge do Censo de 2010: consolidaçóes, tendências e perplexidades. In: TEIXEIRA, F.; MENEZES, R. (Org.). Religióes em Movimento: o censo de 2010. Petrópolis: Vozes, 2013. p. 63-87.

CUNHA, L. A. Educaçáo e religióes: a descolonização religiosa da escola pública. Belo Horizonte: Mazza Edições, 2013.

A laicidade em disputa: religiáo, moral e civismo na educação brasileira. Teias, v. 15, n. 36, p. 5-25, 2014.

A educaçáo brasileira na primeira onda laica: do Império à República. Rio de Janeiro: Edição do Autor: 2017.

CURY, C. R. J. Ideologia e educaçáo brasileira: católicos e liberais. São Paulo: Cortez, 1988.

DIÁRIO CATARINENSE. “Todas as religióes têm curiosidade de ler a Bíblia”, diz vereador Jerônimo Alves. 19 mar. 2015. Disponível em: <http://dc.clicrbs.com.br/sc/ noticias/noticia/2015/03/todas-as-religioes-tem-curiosidade-de-ler-a-biblia-diz-vereadorjeronimo-alves-4722034.html >. Acesso em: 10 de ago. 2015.

FLORIANÓPOLIS. Lei no 6.717 de 5 de julho de 2005. Institui o Dia Municipal da Bíblia. Diário Oficial Eletrônico do Município de Florianópolis, Florianópolis, 17 de julho de 2005 .

Lei no 7.219, de $1^{\circ}$ de dezembro de 2006. Institui o Dia Municipal da Cultura Evangélica e dá Outras Providências. Diário Oficial Eletrônico do Município de Florianópolis, Florianópolis, 7 dez. 2006.

Lei no 7.915, de 22 de julho de 2009. Institui a Semana de Celebração da Cultura e dos Movimentos Evangélicos no Município de Florianópolis. Diário Oficial Eletrônico do Município de Florianópolis, Florianópolis, 30 dez. 2009.

- Lei no 9.375 de 11 de março de 2015. Torna obrigatória a disponibilização de bíblias e dá outras providências. Diário Oficial Eletrônico do Município de Florianópolis, Florianópolis, 15 mar. 2015. 
Lei. no 6.737, de 13 de julho de 2015. Institui a Semana da Bíblia. Diário Oficial Eletrônico do Município de Florianópolis, Florianópolis, 20 de julho de 2005.

FRESTON, P. Breve história do pentecostalismo brasileiro. In: ANTONIAZZI, A. et al. Nem anjos nem demônios: interpretaçôes sociológicas do pentecostalismo. Petrópolis: Vozes, 1994. p. 67-159.

. Neo-Pentecostalism in Brazil: Problems of Definition and the Struggle for Hegemony. Archives de Sciences Sociales Des Religions, v. 105, n. 105, p. 145-162, 1999.

As Duas Transiçôes Futuras: Católicos, Protestantes e Sociedade na América Latina. Ciencias Sociales y Religión, v. 12, n. 12, p. 13-30, 2010.

GEERTZ, C. Nova Luz Sobre a Antropologia. Rio de Janeiro: Jorge Zahar Editores, 2001. GIUMBELLI, E. Ensino Religioso em Escolas Públicas no Brasil: notas de pesquisa. Debates do NER, v. 14, n. 2, p. 50-68, 2009.

Ensino religioso e assistência religiosa no Rio Grande do Sul: quadros exploratórios.

Civitas: Revista de Ciências Sociais, v. 11, n. 2, p. 259-283, 2011.

GUERRA, L. D. Mercado Religioso no Brasil: competição, demanda e a dinâmica da esfera da religião. João Pessoa: Idéia, 2003.

HABERMAS, J. De la tolérance religieuse aux droits naturels. Cités, s/v, n. 13, p. 147-177, 2003.

Entre Naturalismo e Religiáo: estudos filosóficos. Rio de Janeiro: Tempo Brasileiro, 2007.

INSTITUTO BRASILEIRO DE GEOGRAFIA E ESTATÍSTICA. Censo Demográfico 2010: Características da População e dos Domicílios - Florianópolis: Informações Completas. Disponível em: <http://www.cidades.ibge.gov.br/xtras/perfil.php?lang=\&codmun=420540\& search $=\|$ infogr\%E1ficos:-informa\%E7\%F5es-completas>. Acesso em: 10 de ago. 2015.

MACHADO, M. das D. C.; BURITY, J. A Ascensão Política dos Pentecostais no Brasil na Avaliação de Líderes Religiosos. Dados, v. 57, n. 3, p. 601-631, 2014.

MAFRA, C. Números e Narrativas. Debates do NER, v. 14, n. 24, p. 13-25, 2013.

MAHMOOD, S. Religious Reason and Secular Affect: an incommensurable divide?. Critical Inquiry, v. 35, n. 4, p. 836-862, 2009.

MARIANO, R. Laicidade à brasileira: católicos, pentecostais e laicos em disputa na esfera pública. Civitas: Revista de Ciências Sociais, v. 11, n. 2, p. 238-258, 2011. 
MARIZ, C.; CAMPOS, R. B. O pentecostalismo muda o Brasil? Um debate das ciências sociais brasileiras com a antropologia do cristianismo. In: SCOTT, P.; CAMPOS, R. B.; PEREIRA, F. Rumos da Antropologia no Brasil e no Mundo: geopolíticas disciplinares. Recife: Ed. UFPE, 2014. p. 191-214.

MONTERO, P. Religião, laicidade e secularismo: um debate contemporâneo à luz do caso brasileiro. Cultura y Religión, v. 7, n. 2, p. 132-150, 2013.

NATIVIDADE, M.; OLIVEIRA, L. Sexualidades ameaçadoras: religião e homofobias em discursos evangélicos conservadores. Sexualidad, Salud y Sociedad, s/v, n. 2, p. 121-161, 2009.

ORO, A. P. Avanço pentecostal e reaçáo católica. Petrópolis: Vozes, 1996.

PIERUCCI, A. F. Cadê nossa diversidade religiosa?. In: TEIXEIRA, F; MENEZES, R. (Org.). As Religióes no Brasil: continuidades e rupturas. Petrópolis: Vozes, 2006. p. 49-51.

. Eleição 2010: desmoralização eleitoral do moralismo religioso. Novos Estudos Cebrap, s/v, n. 89, 2011, p. 5-16.

. O Crescimento da Liberdade Religiosa e o Declínio da Religiáo Tradicional: a propósito do Censo 2010. In: TEIXEIRA, F; MENEZES, R. (Org.). Religióes em Movimento: o censo de 2010. Petrópolis: Vozes, 2013. p. 49-61.

SANCHIS, P. Religióes, religião... Alguns problemas do sincretismo no campo religioso brasileiro. In: . (Org.). Fiéis e cidadáos: Percursos do sincretismo no Brasil. Rio de Janeiro: EdUERJ, 2001. p. 9-57.

SAVIANI, D. História das Ideias Pedagógicas no Brasil. Campinas: Autores Associados, 2011.

TAYLOR, C. Uma Era Secular. São Leopoldo: Ed. UNISINOS, 2010.

TEIXEIRA, F. Análise sócio-fenomenológica do pluralismo religioso no Brasil. dez. 2012. Disponível em: <http://fteixeira-dialogos.blogspot.com.br/2012/12/0-0-1-2554-14560casa-121-34-17080-14.html>. Acesso em: 20 ago. 2015.

TRIBUNAL DE JUSTIÇA DE SANTA CATARINA. Ação Direta de Inconstitucionalidade n. 2015.021853-1, de Tribunal de Justiça de Santa Catarina. 2015. Disponível em: <http:// busca.tjsc.jus.br/consultadje/consulta.action>. Acesso em: 10 de ago. 2015. 


\section{"Laic State is not Atheistic state": Some reflections about Religion, State and Education from the "law of the bible" in Florianópolis/SC}

\section{Abstract}

The present work aims to discuss the relationship between State and Religion in Brazil, taking as a guideline the discussion about the approval of Law $n^{\circ} 9.374$ of march 11, 2015, which instituted the obligatory of the presence of the bible in schools in Florianópolis/SC, the law was elaborated by the councilman Jerônimo Alves (PRB), also known as Bishop Jerônimo Alves. I am interested here to understand the dispute over the concept of secularism, in which certain groups begin to seek to include their demands in the political agenda, so that, in my understanding, they do not seek with theses actions that they articulate, that passes through bills of laws like this, but also the institutionalization of new commemorative dates and the construction of monuments of religious character, but a semantic extension of the concept of laicity, which comes amid a process of Pentecostal expansion which goes beyond the numerical figures referring to those who claimed to be evangelicals, especially pentecostal evangelicals.

Keywords: Laicity. Sociology of Religion. Religion and Politics. Religion and Education.

Recebido em: 18/11/2016. Aprovado em: 02/05/2017. 